\title{
OPTIMALISASI LAHAN PESISIR MELALUI PENANAMAN SORGUM DENGAN PERLAKUAN PUPUK KANDANG DAN ARANG BIO
}

\author{
Sri Mulyanti, ${ }^{1}$ Puji Harsono ${ }^{2}$, Hery Suhartoyo ${ }^{2}$ \\ ${ }^{1}$ Kantor Pengelolaan Hutan Produksi Mukomuko, Jl. Teluk Rumbia Kab Mukomuko \\ ${ }^{2}$ Jurusan Agroekoteknologi, Jl. Wr. Suprtaman, Kandang Limun Kota Bengkulu \\ ${ }^{3}$ Jurusan Kehutanan, Jl. Wr. Suprtaman, Kandang Limun Kota Bengkulu \\ Email : mulyanti.sri61@yahoo.com
}

\begin{abstract}
ABSTRAK
Penelitian ini bertujuan untuk membandingkan pertumbuhan sorgum pada lahan pesisir, membandingkan kombinasi pupuk kandang dan arang bio dalam budidaya Sorgum dan mengetahui pengaruh interaksi antara kombinasi pupuk kandang dan arang bio pada 3 (tiga) varietas sorgum yaitu Kawali, Keller dan Pahat.Berbagai langkah rekayasa agronomis perlu diambil dalam rangka optimalisasi lahan suboptimal diantaranya adalah dengan pemanfaatan pupuk organik dan arang bio dalam sistem budidaya sorgum.Upaya optimalisasi lahan pesisir dengan pupuk kandang dan arang bio pada sorgum bertujuan untuk mengkaji pemberian formulasi antara pupuk kandang dengan biocharcoal terhadap karakter lingkungan tanah dengan indikator tanaman sorgum. Penelitian menggunakan rancangan acak kelompok lengkap faktorial dengan tiga kali ulangan. Faktor pertama adalah 3 varietas sorgum; Kawali (V1), Keller (V2) dan Pahat(V3). Faktor kedua berupa aplikasi pupuk kandang sapi 10ton/ha + arang bio1 ton/ha (B2), pupuk kandang sapi 5 ton/ha + arang bio 0,5 ton/ha (B1) dan tanpa pupuk kandang + arang bio sebagai pembanding (B0). Hasil penelitian menunjukkan bahwa varietas Keller menghasilkan BKT dan Berat 1000 biji yang berbeda nyata dengan varietas Kawali dan Pahat. Pemberian campuran pupuk kandang dan arang bio mampu meningkatkan kualitas tanah terbukti dengan meningkatnya tinggi tanaman, jumlah daun, bobot segar tanaman, bobot kering tanaman,jumlah ruas.
\end{abstract}

Kata kunci; arang bio, optimalisasi lahan, sorgum

\section{PENDAHULUAN}

Kegiatan pertanian pada tanah berpasir memiliki beberapa kendala yang berkaitan dengan sifat fisik, kimia, biologi tanah dan iklim yang kurang sesuai untuk pertumbuhan tanaman, terlebih lagi tanah berpasir memiliki sifat mudah meloloskan air, kandungan bahan organik yang rendah serta suhu tanah yang tinggi. Kondisi yang demikian tidak menguntungkan dan mendukung pertumbuhan tanaman (Darmawijaya, 1990). Rendahnya bahan organik mempengaruhi tingkat kesuburan tanah. Bahan organik berperan dalam merangsang granulasi agregat dan memantapkannya, memperbaiki kemampuan tanah menahan air, menambah hara $\mathrm{N}, \mathrm{P}$ dan $\mathrm{K}$ dan meningkatkan populasi mikroorganisme tanah. 
Diperlukan teknologi spesifik yang murah dan ramah lingkungan dengan memanfaatkan sumberdaya alam setempat untuk memperbaiki kualitas tanah kawasan pesisir.Oleh karena itu bahan organik yang sederhana dan dapat digunakan sebagai pembenah tanah adalah arang-bio (biocharchoal) dan pupuk yang merupakan pupuk kandang dari kotoran ternak.Selain itu juga diperlukan varietas tanaman yang mampu bertahan terhadap kondisi tanah di lahan pesisir dan memberikan manfaat pada masyarakat di kawasan lahan pesisir.

Sorgum (Sorghum bicolor) merupakan tanaman serelia yang memiliki banyak potensi dan manfaat untuk dikembangkan. Sorgum merupakan tanaman yang mampu beradaptasi luas, dapat tumbuh dan berkembang dengan baik pada kondisi tanah marjinal serta tahan terhadap kekeringan.Selain itu sorgum juga memiliki banyak manfaat sebagai bahan pangan, pakan ternak dan bahan bakar alternatif.

\section{METODE PENELITIAN}

\section{Waktu dan Tempat}

Penelitian ini dilaksanakan pada bulan Mei-Juli 2017 di Desa Kandang Mas Kecamatan Kampung Melayu, dengan ketinggian tempat 5 meter dari permukaan laut (dpl).

\section{Alat dan Bahan}

Alat yang digunakan adalah alat tulis, alat pertanian, meteran, phiband, timbangan analitik, oven, alat hitung, kamera digital dan bahan yang digunakan adalah benih sorgum varietas Kawali, Keller dan Pahat, arang bio dan pupuk kandang.

\section{Rancangan Percobaan}

Penelitian ini menggunakan Rancangan Acak Kelompok Lengkap (RAKL) 2 faktor dan 3 ulangan.Faktor pertama adalah 3 varietas sorgum; Kawali (V1), Keller (V2) dan Pahat (V3). Faktor kedua berupa aplikasi pupuk kandang 0 ton/ha dan arang bio 0 ton/ha (B0), pupuk kandang 5 ton/ha dan arang bio 0,5 ton/ha (B1), pupuk kandang 10 ton/ha dan arang bio 1 ton/ha (B2).

\section{Variabel yang Diamati}

Variabel yang diamati meliputi tinggi tanaman, jumlah daun, diameter batang, berat basah tanaman, berat kering tanaman, jumlah ruas, jumlah daun dan berat malai.

\section{Analisis Data}

Data hasil pengamatan akan dianalisis secara statistik dengan menggunakan uji F 5\% Apabila terdapat pengaruh yang nyata dilanjutkan dengan uji rerata perlakuan menggunakan uji Jarak Berganda Duncan (DMRT) 5\%.

\section{HASIL DAN PEMBAHASAN}

\section{Hasil Pertumbuhan Sorgum}

Hasil analisis varians pengaruh perlakuan terhadap pertumbuhan dan hasil tanaman sorgumdisajikan pada Tabel 1.

Berdasarkan hasil analisis varians menunjukkan bahwa varietas sorgum berpengaruh nyata terhadap bobot kering tanaman dan berpengaruh sangat nyata terhadap bobot malai dan berat 1000 biji, namun berpengaruh tidak nyata terhadap tinggi tanaman, jumlah daun, diameter batang, bobot segar tanaman dan jumlah ruas. 
Tabel 1. Ringkasan hasil analisis varians pertumbuhan sorgum

\begin{tabular}{lcccc}
\hline \multirow{2}{*}{ Variabel Pengamatan } & \multicolumn{3}{c}{ f-hitung } & \multirow{2}{*}{ KK $(\%)$} \\
\cline { 2 - 4 } & Varietas & $\begin{array}{c}\text { Pupuk } \\
\text { kandang }\end{array}$ & Interaksi & \\
\hline Tinggi Tanaman (cm) & $3,58^{\mathrm{ns}}$ & $28,98^{* *}$ & $0,48^{\mathrm{ns}}$ & 15,38 \\
Jumlah Daun (helai) & $0,10^{\mathrm{ns}}$ & $13,81^{* *}$ & $1,14^{\mathrm{ns}}$ & 10,57 \\
Diameter Batang (cm) & $0,05^{\mathrm{ns}}$ & $2,90^{\mathrm{ns}}$ & $0,19^{\mathrm{ns}}$ & 13,32 \\
Bobot Segar Tanaman (gr) & $0,56^{\mathrm{ns}}$ & $32,60^{* *}$ & $1,31^{\mathrm{ns}}$ & 19,02 \\
Bobot Kering Tanaman (gr) & $5,52^{*}$ & $29,26^{* *}$ & $0,75^{\mathrm{ns}}$ & 23,55 \\
Jumlah Ruas (buah) & $0,85^{\mathrm{ns}}$ & $62,22^{* *}$ & $0,65^{\mathrm{ns}}$ & 8,82 \\
Bobot Malai (gr) & $8,46^{* *}$ & $5,96^{*}$ & $1,22^{\mathrm{ns}}$ & 23,15 \\
Berat 1000 Biji (gr) & $4909,88^{* *}$ & $1,89^{\mathrm{ns}}$ & $0,99^{\mathrm{ns}}$ & 25,20 \\
\hline Keterangan : * berpengaruh nyata, $* *=$ berpengaruh sangat nyata, ${ }^{\mathrm{ns}}=$ berpengaruh tidak \\
\multicolumn{4}{c}{ nyata } & \multicolumn{3}{c}{}
\end{tabular}

Sedangkan pupuk kandang berpengaruh sangat nyata terhadap tinggi tanaman, jumlah daun, bobot segar tanaman, bobot kering tanaman, jumlah ruas dan berpengaruh nyata terhadap bobot malai namun berpengaruh tidak nyata terhadap diameter batang. Kombinasi varietas sorgum dan pupuk berpengaruh tidak nyata terhadap tinggi tanaman, jumlah daun, diameter batang, bobot segar tanaman, bobot kering tanaman, jumlah ruas dan bobot malai (Tabel1) sehingga tidak terdapat interksi antara varietas dan kombinasi pemberian pupuk kandang dan arang-bio.

\section{Pengaruh Varietas terhadap Sorgum}

Hasil analisis varians menunjukkan bahwa varietas sorgum berpengaruh nyata terhadap bobot kering tanaman danberpengaruh sangat nyata terhadap bobot malai (Tabel 1). Hasil uji lanjut DMRT taraf 5\% pengaruh varietas sorgum terhadap bobot kering tanaman dan bobot malaiserta rerata pertumbuhan sorgum disajikan pada Tabel 2.

Hasil uji DMRT taraf 5\% menunjukkan bahwa varietas Keller menghasilkan bobot kering tanaman terbobot dan berat 1000 biji terberat yang berbeda nyata dengan varietas Kawali dan Pahat.Sedangkan varietas Pahat menghasilkan bobot kering tanaman terendah yang berbeda tidak nyata dengan varietas Kawali, namun berbeda nyata dengan varietas Keller. Bobot kering tanaman pada varietas Keller adalah seberat 86,31 gram atau lebih tinggi 30,38\% dari bobot kering tanaman pada varietas Pahat yaitu seberat 61,10 gram.

Hal ini menunjukkan bahwa varieta Keller menghasilkan berat kering tanaman yang lebih berat dibandingkan Kawali dan Pahat.Perbedaan varietas tanaman sorgum memberikan pengaruh yang nyata terhadap akumulasi bahan kering tanaman sorgum. Perbedaan genetik dapat dilihat jika varietas berbeda di tanam pada lingkungan yang sama maka akan menunjukkan perbedan yang nyata (Fitter dan Hay, 1991 dalam Sutrisna et al, 2013)

Hal ini berkaitan dengan perbedaan kemampuan varietas tanaman sorgum dalam melakukan fotosintesis dan mengakumulasikan ke organ tanaman.Menurut Poerwanto (2003) bahwa produktivitastanamansangattergantung pada kemampuan tanamanuntuk melakukan fotosintesis 
danmengalokasikan sebagian besar hasilfotosintesis tersebut ke organ tanaman.Berat kering tanaman yang semakin tinggi menunjukkan proses fotosintesis yang berjalan dengan baik .

Hasil penelitian juga menunjukkan bahwa varietas Kawali menghasilkan berat malai terberat yang berbeda tidak nyata dengan varietas Pahat, namun berbeda nyata dengan varietas Keller. Sedangkan varietas Keller menghasilkan berat malai teringan yang berbeda tidak nyata dengan varietas Pahat, namun berbeda nyata dengan varietas Kawali. Berat malai sorgum pada varietas Kawali adalah sebesar 78,06 gram atau lebih tinggi $57,88 \%$ dari berat malai pada varietas Keller yaitu sebesar 49,44 gram.

Untuk hasil berat 1000 biji di dapat bahwa berat 1000 biji Keller berbeda nyata dengan berat 1000 biji Kawali dan Pahat, sedangkan berat 1000 biji Kawali tidak berbeda nyata dengan Pahat. Berat 1000 biji Keller adalah 30,08 gram, Kawali 19,92 gram dan Pahat 29,19 gram.Berat 1000 biji suatu varietas penting diketahui jika biji tersebut akan dijadikan benih. Semakin berat bobot benih 1000 biji kecepatan kecambah benih semakin meningkat (Sutopo, 2002)
Secara umum hasil penelitian menunjukkan bahwa varietas Keller lebih baik pertumbuhannya dari pada varietas Kawali dan Pahat, akan tetapi perbedaan itu tidaklah terlalu signifikan sehingga terlihat bahwa ketiga varietas sorgum tersebut dapat tumbuh dengan baik di tanah pesisir.

\section{Pengaruh Pupuk Kandang dan Arang Bio terhadap Sorgum}

Hasil analisis varians menunjukkan bahwa pemberian pupuk kandangdan arang bioberpengaruh sangat nyata terhadap tinggi tanaman, jumlah daun, bobot segar tanaman, bobot kering tanaman, jumlah ruas dan bobot malai (Tabel 1). Hasil uji lanjut DMRT taraf $5 \%$ dan rerata pertumbuhan sorgum akibat pemberian pupuk kandang disajikan pada Tabel 3.

Hasil uji DMRT taraf 5\% menunjukkan bahwa pemberian pupuk kandang 5 ton/ha dan arang bio 0,5 ton/ha tinggi tanaman yang lebih tinggi $(264,11 \mathrm{~cm})$, jumlah daun lebih banyak $(11,22$ helai), bobot segar tanaman lebih berat (580,00 gram), bobot kering tanaman lebih berat (106,28 gram), jumlah ruas lebih banyak (10,78 buah)yang berbeda nyata dengan tanpa pemberian pupuk kandang dan pemberian pupuk kandang 10 ton/ha dan arang bio 1 ton/ha.

Tabel 3. Rerata hasil penelitian pengaruh pupuk kandang terhadap sorgum

\begin{tabular}{ccrrrrrrl}
\hline $\begin{array}{c}\text { Pupuk } \\
\text { kandang }\end{array}$ & TT (cm) & JD (helai) & DB (cm) & BST (gr) & BKT (gr) & JR (buah) & BM (gr) & $\begin{array}{c}\text { B } 1000 \\
\text { biji (gr) }\end{array}$ \\
\hline B0 & $176,11 \mathrm{~b}$ & $8,78 \mathrm{~b}$ & 1,99 & $311,67 \mathrm{~b}$ & $50,56 \mathrm{~b}$ & $7,67 \mathrm{~b}$ & $61,67 \mathrm{~b}$ & 26,27 \\
B1 & $264,11 \mathrm{a}$ & $11,22 \mathrm{a}$ & 2,29 & $580,00 \mathrm{a}$ & $106,28 \mathrm{a}$ & $10,78 \mathrm{a}$ & $52,92 \mathrm{~b}$ & 26,45 \\
B2 & $161,78 \mathrm{~b}$ & $9,33 \mathrm{~b}$ & 2,25 & $336,67 \mathrm{~b}$ & $57,54 \mathrm{~b}$ & $7,11 \mathrm{~b}$ & $76,67 \mathrm{a}$ & 26,46 \\
\hline
\end{tabular}

Ket $: 1 . \mathrm{T}=$ tinggi tanaman, $\mathrm{JD}=$ jumlah daun, $\mathrm{DB}=$ diameter batang, $\mathrm{BST}=$ bobot segar tanaman, $\mathrm{BKT}=$ bobot kering tanaman, $\mathrm{JR}=$ jumlah ruas, $\mathrm{BM}=$ berat malai, B0 = tanpa pupuk kandang, B1= pupuk kandang 5 ton/ha dan arang bio 0,5 ton/ha, B2= pupuk kandang 10 ton/ha dan arang bio 1 ton/ha

2. Angka-angka yang diikuti oleh huruf yang berbeda pada kolom yang sama berbeda nyata padauji DMRT $5 \%$. 
Pemberian pupuk kandang 10 ton/ha dan arang bio 1 ton/ha menghasilkantinggi tanaman lebih rendah $(161,78 \mathrm{~cm})$ dan jumlah ruas lebih sedikit (7,11 buah) yang berbeda tidak nyata dengan tanpa pemberian pupuk kandang, namun berbeda nyata dengan pemberian pupuk kandang 5 ton/ha dan arang bio 0,5 ton/ha. Sedangkan pemberian pupuk kandang 10 ton/ha dan arang bio 1 ton/ha menghasilkan berat malai lebih berat dari pada pemberianpupuk kandang 5 ton/ha dan arang bio 0,5 ton/ha dan tanpa pemberian pupuk kandangyaitu 76,67 gram. Hal ini dikarenakan untuk pembentukan biji diperlukan nutrisi yang lebih dalam menunjang produktivitas tanaman.

Sedangkan tanpa pemberian pupuk kandang menghasilkan jumlah daun terendah $(8,78$ helai), diameter batang terendah $(1,99 \mathrm{~cm})$, bobot segar tanaman terendah $(311,67$ gram), dan bobot kering tanaman terendah $(50,56$ gram) yang berbeda tidak nyata dengan pemberian pupuk kandang 10 ton/ha dan arang bio 1 ton/ha, namun berbeda nyata dengan pemberian pupuk kandang 5 ton/ha dan arang bio 0,5 ton/ha. Hal ini karena pemberian pupuk kandang 5 ton/ha dan arang bio 0,5 ton/ha mampu meningkatkan daya dukung lingkungan lebih baik daripada tanpa pemberian pupuk kandang dan pemberian pupuk kandang 10 ton/ha dan arang bio 1 ton/ha.

Secara umum hasil penelitian menunjukkan bahwa pemberian bahan organik menghasilkan pertumbuhan dan hasil sorgum lebih baik daripada tanapa pemberian bahan organik.Hal ini karena lahan yang digunakan dalam penelitian ini adalah lahan pesisir, sehingga tanpa pemberian bahan organik kemampuan tanaman untuk dapat tumbuh menjadi rendah.Lahan pasir pantai merupakan lahan marjinal yang memiliki produktivitasrendah.

Produktivitas lahan pasir pantai yang rendah disebabkan oleh faktor pembatasyang berupa kemampuan memegang dan menyimpan air rendah, infiltrasi dan evaporasitinggi, kesuburan dan bahan organik sangat rendah dan efisiensi penggunaan air rendah (Kertonegoro, 2001).

Pemilihan pupuk kandang dan arang-bio sebagai perlakuan dalam optimalisasi lahan pesisir dikarenakan pupuk kandang merupakan sumber hara bagi tanaman dan memperbaiki sifat fisik, biologi dan kimia tanah. Terutama tanah berpasir yangmemiliki kapasitas KTK rendah, daya simpan air rendah, suhu tanah di siang hari tinggi, kecepatan angin dan laju evaporasi sangat tinggi sehingga menjadi kurang produktif untuk dijadikan lahan pertanian.

Dalam penelitian ini pengamatan dilakukan pada 60 HST untuk mendapatkan data hasil hijaun ternak. Pada pengamatan yang dilakukan, hasil hijauan tanaman sorgum dapat dilihat dari bobot segar tanaman pada 60 HST yaitu 580 gr pada pemberian pupuk kandang 5 ton/ha dan arang bio 0,5 ton/ha. Hasil hijaun tersebut lebih besar dihasilkan pada pemberian pupuk kandang 5 ton/ha dan arang bio 10 ton/ha dibandingkan pada pemberian pupuk kandang 5 ton/ha dan arang bio 1 ton/ha dan tanpa pemberian pupuk.

Hijauan sorgum ini sangat bermanfaat sebagai pakan ternak terutama tanaman yang masih muda dan sedang berbunga. Supriyanto (2010), menyatakan bahwa batang dan daun sorgum dapat dimanfaatkan untuk pakan ternak, terutama sapi karena batang sorgum yang renyah dan manis. Selain itu dapat juga menjadi pakan 
ternak ruminansia lainnya seperti kambing.

Potensi sorgum sebagai pakan ternak patut untuk dikembangkan karena sifat tanaman sorgum yang mudah untuk tumbuh dan beradaptasi di tempat tumbuhnya, budidaya yang mudah dan murah serta memiliki manfaat ekonomi lainnya. Pengembangan sorgum sebagai pakan ternak dapat menjadi salah satu solusi untuk memenuhi kurangnya pasokan pakan ternak yang terjadi di Indonesia . Budidaya sorgum manis di Indonesia masih belum intensif dilakukan oleh masyarakat, padahal potensinya sangat baik untuk memenuhi kebutuhan pakan ternak yang selama ini didominasi oleh pakan impor (Puspitasari dkk, 2012)

\section{Analisis tanah}

Analisa tanah dilakukan sebelum dan sesudah kegiatan penanaman untuk melihat unsur Nitrogen $(\mathrm{N})$, Fosfor $(\mathrm{P})$ dan Kalium (K) yang merupakan unsur hara makro utama di dalam tanah. N, P dan $\mathrm{K}$ menjadi indikator utama dalam melihat kesuburan tanah. Dari hasil analisis tanah lahan penelitiandapat terlihat bahwa setelah penanaman unsur hara N, P, K dan C-organik lebih banyak dari pada sebelum kegiatan penanaman. Hal ini dikarenakan adanya pemberian pupuk kandang dan arang bio pada tanah tersebut. Salah satu upaya dalam meningkatkan unsur hara di dalam tanah adalah dengan pemupukan. Pemupukan akan efektif dan efisien apabila diberikan dengan cara dan waktu yang tepat yaitu dosis yang optimum dam pupuk yang sesuai dengan jenis tanaman (Kaderi, 1998). Hasil analisa tanah sebelum dan setelah kegiatan penelitian dapat dilihat pada Tabel 4.

Hartatik dan Setyorini 2009 menyatakan pemberian bahan organik memiliki peranan cukup besar terhadap perbaikan sifat fisika, kimia, dan biologi tanah.Sejalan dengan hal tersebut Parker, (2004) menyatakan penambahan bahan organik pada tanah berpasir dapat memperbaiki retensi hara dan air. Pemberian pupuk kandangakan membantu meningkatkan kesuburan tanah melalui pelepasan nitrogen dan unsur hara lain secara perlahan-lahan melalui proses mineralisasi.

Tabel 4.4 Hasil analisa sifat kimia tanah sebelum dan sesudah penelitian

\begin{tabular}{lcccc}
\hline Parameter Tanah & N-total $(\%)$ & P-bray $(\mathrm{ppm})$ & $\mathrm{K}(\mathrm{mg} / 100 \mathrm{gr})$ & $\begin{array}{c}\text { C-organik } \\
(\%)\end{array}$ \\
\hline Tanah awal & 0,22 & 0,28 & 4,42 & 2,44 \\
& $(0,21-0,50)$ & $(<10)$ & $(<10)$ & $(2,01-$ \\
& Sedang & Sangat & Sangat & $3,00)$ \\
& & Rendah & Rendah & Sedang \\
\hline Aplikasi bahan & 0,39 & 2,82 & 8,86 & 3,50 \\
organic & $(0,21-0,50)$ & $(<10)$ & $(<10)$ & $(2,01-$ \\
& Sedang & Sangat & Sangat & $3,00)$ \\
& & Rendah & Rendah & Tinggi \\
\hline
\end{tabular}

Keterangan :Hasil analisa laboraterium Ilmu Tanah Universitas Bengkulu 
Bahan organik dapat memperbaiki aerasi tanah, penetrasi akar, penyerapan air, dan mengurangi pengerasan permukaan tanah.Kebutuhan tanaman akan unsur hara adalah hal yang mutlak, kekurangan unsur hara akan menghambat pertumbuhan tanaman dan penurunan produktivitas dan apabila tanaman kelebihan unsur hara maka akan bersifat toksin (keracunan).

\section{KESIMPULAN DAN SARAN}

\section{Kesimpulan}

Berdasarkan disimpulkan bahwa :

1. Varietas Keller memberikan respon yang lebih baik pertumbuhannya di tanah pesisir, akan tetapi perbedaan pertumbuhan ketiga varietas tidaklah terlalu signifikan sehingga Kawali, Keller dan Pahat memberikan respon pertumbuhan yang cukup baik di tanah pesisir.

2. Secara umum pemberian pupuk kandang 5 ton/ha dan arang bio 0,5 ton/ha menyokong pertumbuhan yang lebih baik pada tanah pesisir.

3. Tidak terdapat interaksi antara kombinasi pemberian pupuk kandang dan arang bio terhadap ketiga varietas sorgum tersebut (Kawali, Keller, Pahat).

\section{DAFTAR PUSTAKA}

Darmawijaya, I. 1990. Klasifikasi Tanah: Dasar teori bagi peneliti tanah dan pelaksanaan pertanian di Indonesia. Yogyakarta: Gadjah Mada University Press dalam Tewu, R.W.G., K. L. Theffie dan D.D Pioh. 2016. Kajian sifat fisik tanah pada tanah berpasir di Desa Noongan Kecamatan Lmaongan Barat.
Fitter, A. H., dan R. K. M. Hay. 1991.

Fisiologi Lingkungan Tanaman.Penerjemah Sri Andani dan Purbayanti.UGM Press.Yogyakarta dalam Sutrisna.N., N. Sunandar dan A. Zubair. 2013. Uji adaptasi Beberapa Varietas Sorgum (Sorghum bicolor L.) pada lahan kering di Kabupaten Ciamis.Jurnal Lahan Sub Optimal 2(2): 137-143.

Hartatik W, Setyorini D . 2009. Pengaruh pupuk kandang terhadap sifat kimia tanah dan produksi tanaman padi sawah organik. Prosiding Seminar Nasional dan Dialog Sumberdaya Lahan Pertanian. Bogor (ID). hlm 21-35.

Kaderi, H. 1998. Gejala keracunan dan Kahat unsur hara pada tanaman padi. Badan Penelitian dan Pengembangan Pertanian. Buletin Teknik Pertanian. III (I) ; 5-7.

Kertonegoro, B. D. 2001. Gumuk Pasir Pantai Di D.I. Yogyakarta : Potensi danPemanfaatannya untuk Pertanian Berkelanjutan. Prosiding SeminarNasional Pemanfaatan Sumberdaya Lokal Untuk PembangunanPertanian Berkelanjutan. Universitas Wangsa Manggala.

Parker R. 2004. Introduction to Plant Science. United States: Delmar Learning.

Poerwanto, R. 2003. Peran Manajemen Budidaya Tanaman Dalam Peningkatan Ketersediaa dan Mutu Buah- buahan. Orasi Ilmiah Guru Besar Tetap Ilmu Hortikultura Fakultas Pertanian, Institut Pertanian Bogor, Bogor. 
Puspitasari, G., D. Kastono dan S. Waluyo. 2012. Pertumbuhan dan hasil sorgum manis (sorghum bicolor (1.) Moench) tanam baru dan ratoon pada jarak tanam berbeda. Fakultas Pertanian. UGM.Yogyakarta.
Supriyanto. 2010. Pengembangan Sorgum Dilahan Kering Untuk Memenuhi Kebutuhan Pangan, Pakan, Energi dan Industri. SEAMEO-BIOTROP.IPB. Bogor.

Sutopo, L. 2002. Teknologi Benih. Rajawali Pers. Jakarta. 